\title{
SOCIAL AND HISTORIC CONTEXTUALITY OF CONTEMPORARY ALBANIAN LITERATURE (Albania, Macedonia and Montenegro)
}

Prof. Ass. Vjolca DIBRA

\section{Article info}

\section{Article history:}

Accepted 16 December 2018

Available online 31 December 2018

\section{Keywords:}

Literature, history, World War II, writer, contemporary, education, publisher

\begin{abstract}
A b s t r a c t
To reach the reader of 2018, Contemporary Albanian literature has overcome many obstacles and politics ideology. She felt violated by a certain, imposing and savage ideology. The method of socialist realism by some writers was embraced with delight and conviction, and from some others it was used for compromise to bring to light their works, which, in case of incompatibility with the relevant ideology, was banned from publishing. However, given that literature is the creation of the human spirit, it is unnatural to think that all this literature of this period has not expressed their feelings, sorrows, dreams and their love. Perhaps we can argue with conviction, which has been a memory for the past and also a dream for the future. This literature overwhelmed the content imposed in 1945 and continued to be the most rebellious. The national liberation war was not the subject of the 1960s literature, which was more stubborn than what was written fifteen years ago, even by the same authors. Here, summed up as a great deal in the history of contemporary literature, find the first and the foremost authors of this literature, their best works, publishers, and their echoes in the language of translation.
\end{abstract}

\section{Introduction}

These two names, Contemporary Albanian literature, as well as Modern Albanian Literature, are also encountered in public universities at the Faculty of Philology in Tirana, Korça, Durrës, Gjirokastra, and in private colleges there. But these names, for those who do not know, are quite different. They are different, but we have seen that the professors of literary science do not distinguish them.

We are commencing this presentation of contemporary Albanian authors and literature moving to Albania, Macedonia, Montenegro, to give a summary of its situation today. In order to clarify it, we shall emphasize that Arbëresh authors of Italy, since they have been left marginalized for a long time by all Albanian scholars, we will leave them out of this treatise too, with the intention of making a special treatise for their conditions of publication and creation of literary works over the years, which have remained silent and unfamiliar because the criticism did not deal with their work and with them. And, having knowledge of their works and the expectations that criticism and studies have had over the years, we will highlight one for analysis, and another that is less mentioned in contemporary Albanian literature will be mentioned only for the statistics matter.

A presentation of authors and works of contemporary Albanian literature in the monograph Contemporary Albanian Literature: the interplay of poetics and the decoding of metaphysical realities in contemporary novel has been done by the scholar Arben Prendi. The author continues this same study activity with the publication of the book Problems, authors and works from contemporary Albanian literature.

In Albania, writers Petro Marko, Jakov Xoxa, Ismail Kadare, Bilall Xhaferi, Kasem Trebeshina, Dritëro Agolli, Fatos Arapi, Fatos Kongoli and few others were trying to show their creative individuality, but some of them were impeded by the party from expressing their opinion freely, as it checked their works before the publication and gave them strict criticism even on the handing over of the manuscript for publication, even on the occasion of their publication, thus they would be returned for rewriting by the 
authorities of Enver Hoxha's party, people who served politically and culturally.

\section{Contemporary Albanian literature, authors, editions and publishers}

\section{The case of Macedonia}

Authors of contemporary Albanian literature, like those of the previous periods, presented their poetical, prosaic, dramatic, critical, and essayistic talent first in journals. For example, in Macedonia at the beginning of the '50s, Albanian authors "started publishing poems, stories, essays, critics, story fragments, novels and other types of literature on the pages of the weekly Flaka e vëllazërimit, the only journal published in Albanian in Skopje. The authors of these writings were mainly from Macedonia, very rarely there would be one from Kosovo" and Albania (Aliu, 2008). These genres of writing in this literary journal were written by writers from Macedonia: Adem Gajtani, Murteza Peza, Fejzi Bojko, Nexhat Pustina, Sabaudin Ajdini, Sabedin Gjura, Murat Isaku, Lutfi Rusi, and some others less frequently, then Adem Gajtani more often, who went from Podujeva, Kosovo, to Skopje and started living there and working as an editor of Flaka e Vëllazërimit, and also started publishing his texts on this journal, but also those of Murat Isaku, Abdylaziz Islami and others whose profession was to create. In the sixties, the essayist with family origin from Pogradec, Luan Starova, joined this period of literature quite emphatically, followed by other creators from Pollog, such as Mustafa Laçi, Xhabir Ahmeti, Ibrahim Veliu, Nijazi Saliu, Halit Basha (in Dibra), Nexhat Mustafa, Ali Aliu, Nuhi and Agim Vinca (in Struga), who, along with the first one, had moved to live and work in Kosovo, keeping both citizenships to this day. In addition to them, other writers and researchers came to study, live and work in Kosovo, such as: Ali Aliu, Eqrem Basha who had presented the beginnings and promises of their authorship for the first time in the Albanian press of Macedonia.

Some of these writers, one or two years after being introduced on this journal, also started publishing books on the enterprise with the same name, Flaka e vëllazërimit, under the care of the editorial office members of this publishing enterprise. Meanwhile, the same started publishing books of the writers from Kosovo who would send their writings to this publishing body for their publication.

Through the journal Flaka e vëllazërimit and this same enterprise, contemporary Albanian literature of Macedonia began to penetrate even outside the Macedonian land; old and new writings began to be written and come to light, whose authors were looking forward to seeing them on the hands of Albanian readers. Thus, these Albanian creators, until late ' 80 s, were the most popular authors in Macedonia.

Nonetheless, contemporary Albanian literature in Macedonia continues its journey with other writers, some of whom have become famous for quite a long time now; some others have started to be acknowledged and become famous for their publications and republications of their works outside Macedonia but also due to their literary works being translated in English, French, and German.

Today there are some Albanian writers in Macedonia who are famous even beyond their country for their serious literature which has been published by six or seven Albanian publishers of Macedonia in total (Skopje, Logos, Sira, Rezna, ARS-ZZ, Fokus) who, in the annual competitions of the Ministry of Culture of Macedonia for publication of works, deposit writings of authors and receive considerable financial support, but they publish the books rapidly, without anyone swallowing their content seriously, even without being edited. Therefore, albeit older and less modern than the ones that are still alive and writing, the works of Murat Isaku and Abdylaziz Ismaili are still read and appreciated. Particularly requested by readers and awarded by cultural state institutions, inside and outside Macedonia, are the works of Kim Mehmeti (in Kosovo), of Luan Starova (in Albania), and of Eqrem Basha (in Kosovo), while great honor continues to be paid to Resul Shabani for his prosaic contribution, Nehas Sopaj for his studies, and Nebi Islami (for drama), and Mexhid Mehmeti for children's literature.

This caravan of writers, by reading and interpreting the literary works of the ones mentioned above, were joined by Shkëlzen Halimi, Avni Halimi, Rexhep Zllatku, Halil Zendeli, Ilir Ajdini, Hajri Shaqiri, Luljeta Isaku, Lindita Aliu, followed by the young creators, whose work and study approach towards literature is distinguished by that of the former ones and by us as well. Here we mention Fatmir Sulejmani, Lulzim Haziri, Shazim Mehmeti, Teuta Arifi, Salajdin Salihu, Berton Sulejmani, Halil Zendeli, Ahmet Selmani, Zejnepe Rexhepi, Lindita Ahmeti. "The latter, with her three poetry volumes published until now, can be convincingly listed among the most famous names of contemporary Albanian literature. We are talking about an extraordinary talent, a cultural molding, particularly from the antique literary and philosophical era, also unique and rare. The metaphysical reflection and the high degree of emotion, of creative concern in the poetry of Lindita Ahmeti, result in a perfect lyrical synthesis similar to the most contemporary trends 
in worldwide poetry" (Aliu, 2008).

However, contemporary Albanian literature in Macedonia, due to the lack of support from the state institutions which it should receive just as the Macedonian literature does, in particular from the Ministry of Culture of Macedonia, and due to the lack of support for publication and lack of attention for the works of Albanian writers by the two biggest Albanian publishers in this country, namely "Logos A" and "Sira", the expectations of this contemporary literature, including other reasons as well, have started to decrease because of the volume of publications, number of authors, value, and circulation. We really hope that the contemporary Albanian literature, especially that of Macedonia, will be discussed not only in the International Seminar of Albanology in Tetovo which has been organized by the Rector of State University of Tetova in cooperation with the Faculty of Philology of this university once a year in October, for 12 years now, but we also hope that it will be written and talked about during every year of the age of literature.

\section{Contemporary Albanian literature, authors, editions, and publishers}

\section{The case of Montenegro}

The contemporary Albanian literature of Montenegro has very few names of creators. It is a very poor literature in relation to the number of Albanian inhabitants. Even the few writers who come from that area have reached their fame through the literary works they created in Kosovo at a very young age. Yet, these few persons are not scarce to our literature because they are great names. They are Rexhep Qosja, Mehmet Kraja, and late Basri Çapriqi, who have occupied a meritorious place in the Albanian literature: the first with monographic studies, with a rigorous critical approach, with publicist writings, with dramas containing mythical elements, and postmodern novels; the second with novels, essays, and opinions; the third with poetry and studies. However, none of them, regardless of their considerably serious writings, penetrated into the international literature as much as some others did who became writers "by force". Qosja's works were translated into Serbian, Slovenian, Croatian, they reached mainly the Balkans' nations, very few of them were translated into French, Dutch, Swedish, and Arabic. But the works of Kraja and Çapriqi have not been translated in all these languages. Had these three writers not existed, we would have presented this literature only with Anton and Nikollë Berisha, who are much less known because, for their age, around 60 years old, they have worked very little in both science and literary composition. They have only published two books each.

Qosja, Kraja, Çapriqi and Anton write and publish in Kosovo, whereas Nikolla in Montenegro. The first ones publish their works with public and private publishers in Kosovo, Serbia, Albania and Macedonia, whereas the latter only in his home country, in Montenegro.

Qosja published his first literary and scientific writings in the journal Jeta e Re, whereas his works and books were initially published by the Editorial Office, Rilindja, by Flaka e Vëllazërimit in Skopje, then by the Institute of Albanology, and the Publishing House, Toena, in Tirana.

Kraja published his first literary writings in the journal Jeta e Re, whereas his works and books were first published by the Editorial Office, Rilindja, then by the Kosovo Academy of Arts and Sciences, and recently by the Publishing House, Onufri.

The poet and researcher Çapriqi started his opus in these two fields in the journal Jeta e Re, in the newspaper Rilindja, Zëri i rinisë, etc., whereas his poetry and study books were first published by the Editorial Office, Rilindja, then by the PEN Centre of Kosovo which he himself used to lead, by Rozafa which was led by his friend, Sali Bashota, and by Faik Konica.

The two Berishas, Anton and Nikolla, write rarely and publish even more rarely than they write. The first one has published two study works in Kosovo by the Publishing House Buzuku, the second in Montenegro Illyricumi, and in Albania by Toena.

There are also some young Albanian writers in Montenegro who, if they follow the path of the work of the first three, could occupy a place in the contemporary Albanian literature.

\section{Contemporary Albanian literature, authors, publications, and publishers}

\section{The case of Albania}

Scrutinizing the space of contemporary Albanian literature, we can see that each Albanian country already has some "greater", better, more awarded writers, and who are more famous than others even outside Albanian territories, who started making their literary opus public in the literary periodical press and daily newspapers of Albania, such as Demokratia, Përpjekja shqiptare, Neoshqiptarizma, Hylli i Dritës, Leka, Minerva, Koha, etc. After making accounts of their data, it turns out there is only one Albanian author, that of The General of the Dead Army, of Broken April, of Chronicle in Stone and a wide range of other works which have brought him national awards in the Albanian 
lands and abroad for the literary works he has written and published over the years, for sixty years, whose name continues to be mentioned for twenty years now every time the days of Nobel Prize award in literature approach. This writer has sent the Albanian literature, his works - and through them - the Albanian history, culture, anthropology, and ethnology to 40 countries and thousands of cities around the world. This writer, but also his contemporaries, started writing and publishing under communist political and historical conditions. In contrast to him who did not suffer physically, those writers who started protecting the party suffered worse (because their work is considered worthless today) and others who started opposing Enver Hoxha (who called on behalf of the persecution and censure that they faced with, and which, undoubtedly, was actually done to some of them). Therefore, "what happened from 1973 to at least 1975 was a dominion of terror against Albanians and Albanian intellectuals, which can be compared to Stalinist cleansing of the 1930s. Those years were a huge step behind for the development of the Albanian literature and culture. In the spring of 1973, one hundred and thirty writers and artists announced that they were leaving the cities to work in the fields and construction sites with the aim of strengthening their connections to the working class. Poets and prose writers entered into a competition with one another by demonstrating revolutionary zeal and by refusing foreign, liberal influences. Those who were less convincing and had less publications touched by the influence of liberalism were sent to remote places or were imprisoned. The most fortunate ones only lost the right of publication. Almost all major writers had at least one work removed from circulation and "turned into cardboard". Learning foreign languages was strictly forbidden, whereas those who had the bad luck of speaking French or Italian found themselves in an uncomfortable position" (Elsie, 1997).

After World War II, many Albanian writers and intellectuals of Albania were arrested and imprisoned, such as: playwrights Kristo Floqi (1873-1951) and Etëhem Haxhiademi (1902-1952), writer and Muslim publisher, Hafiz Ibrahim Dalliu (1878-1952), the minister of Education, Mirash Avanaj (1891-1953), who died in prison, and the poet Dionis Gjergj Bubani (1926); short story writer Mitrush Kuteli (1907-1967), romanticist Petro Marko (1913-1991), poet Sejfulla Malëshova (1900-1971), writer Musine Kokalari (1917-1983), poet and researcher Arshi Pipa (1921-1997), Bektashi poet Ibrahim Hasnaj (1912-1995), poet Nexhat Hakiu (1917-1978), poet Andrea Varfi (1914-1992), translators Jusuf Vrioni (1916-2001) and Pashko Gjeci (19182010), romanticist Mustafa Greblleshi (1922-1986), publicist Dionis Miçaço (1908-), poet Kudret Kokoshi (1907-1991), romanticist and Publisher Anton S. Frashëri (1892-1965), comedian and relentless translator Mid'hat Araniti (1912-1992), linguist Selman Riza (1909-1988), critic Filip Fishta (19011973), folklorists Father Donat Kurti (1903-1969) and Stavro Frashëri from Kavaja, and writer Lazër Radi (1916-1998), and many other writers who did not write by the orders of the party, therefore they suffered punishments of the most various forms by the communist regime of Enver Hoxha, who despised each writer, young and old. However, neither the above mentioned nor the ones in this period, like Dhimitër Shuteriqi, Shevqet Musaraj, Sterjo Spasse, Fatmir Gjata, Jakov Xoxa, Ali Abdihoxha, Aleks Çaçi, Mark Gurkuqi, Luan Qafëzezi, Llazar Siliqi, etc., could not be stopped by Enver with his numerous authorities and his harsh decisions which he used to take in the blink of an eye.

Regardless of the limitations and barbarian measures of socialist realism that he applied on Albanian authors and their works, Albanian literature marked advances in the seventies and eighties, with the emergence of Ismail Kadare (1936-), who started writing and publishing parallel to this generation of writers but who, in contrast to them, according to young critics and authors, was considered an auspicious initiative for the Albanian literature to move forward. The signs of his opus appear in the horizon with poems, and then with novels, but it is the novels that made him known in the world, mainly the novel The General of the Dead Army, The Monster, Broken April, The Castle, Chronicle in Stone, The Traitor's Niche, Doruntine, The Wedding Procession Turned into Ice, The Dark Year, and some other ones from his 60 published works. Since he was originally from the same city as the communist leader, Enver Hoxha, he had his complete support, which the writer today denies. Obviously, his success was also assured since the translation of his works into another language was enabled. At the end of the day, although he could do to him what he did to the others, Hoxha never sent Kadare to prison even when the latter would sometimes "scratch" him. Nonetheless, he received warnings about his works by lead members of Hoxha's party, which he had to edit and tone down in every re-edition.

As concerns the literature of this writer and his personality, I do not know of anyone having described his freedom of writing and his values better than Elsie did: "Ismail Kadare did his utmost to emancipate Albanian literature, which, thanks to his talent and support from the regime, reigned as an absolute monarch in the seventies and eighties.

In many cases during the long years of heavy dictatorship, he expressed open criticism of the level in the field of literature and art, while at the same time giving his unconditional support to the political system from which he himself has undoubtedly suffered. This has led many adversaries to refer to him later as the 'royal 
court writer' or 'exponent of the regime', opponents who have questioned even if it was indeed a secret dissident, as he tried, somewhat thickly, to prove it from exile in Paris. Be that as it may, there is no doubt that Ismail Kadare used his relative freedom and his talent under the dictatorship to make subtle attacks against the regime in the form of the allegories we encounter, as we have seen, everywhere in his works. However, it would be best if perhaps Ismail Kadare were valued from a completely literary point of view, as the author of works ranging from an average to excellent grade. Political analysis of conformism or dissent in its prose should be left to the future" (Elsie, 1997).

This glorious researcher of Albanian literature in the world, inside and outside the boundaries of our literature, has been quite supportive of creative and talented writers, such as Petro Marko, Kasëm Trebeshina, Sabri Godo, Dritëro Agolli, Naum Prifti, Dhimitër Xhuvani, Kapllan Resuli, Skënder Drini, Vath Koreshi, Teodor Laço, Nasri Lera, Koço Kosta, and many others, whose literature, from professional Albanian and international criticism, is in many occasions appreciated more than that of Kadare.

Good writers of the Albanian literature, for many readers' taste, who write for adults and children, prose and poetry and drama, are considered to be Bilall Xhaferi, Ndoc Papleka, Martin Camaj, Kiço Blushi, Neshat Tozaj, Fatos Kongoli, Zija Çela, Betim Muço, Roland Gjoza, Valter File, Bashkim Shehu, Preç Zogaj, Teodor Keko, Besnik Mustafaj, Ridvan Dibra, Lazër Stani, Elena Kadare, Diana Çuli, Mira Meksi, Mimoz Ahmeti, Mehmet Myftiu, Astrit Delvina, Trifon Xhagjika, Pjetër Arbnori, Fatos Arapi, Xhevahir Spahiu, Zihni Sako, Kolë Jakova, Spiro Çomora, Sulejman Pitarka, Ndrekë Luca, Loni Papa, Fadil Paçrami, Xhemal Broja, Ibrahim Uruçi, Selman Vaçari, Fadil Kraja, Naum Prifti, Fahri Balliu, Artur Zheji, Zef Zorba, Dhimitër L. Gjoka, Dhori Qiriazi, Qamil Buxheli, Moikom Zeqo, Zef Zorba, Mira Meksi, Klara Buda, Xhevat Beqaraj, Natasha Lako, Elvira Dones, Ben Blushi, Stefan Çapaliku, Teodor Keko, Teodor Laço, Vaid Hyzoti, Visar Zhiti, Xhevahir Spahiu, Ervin Hatibi, Flutura Açka, Gazmend Krasniqi, Gëzim Hajdari, Gridor Jovani, Gjekë Marinaj, Nonda Bulka, Irma Kurti, Irhan Jubica, Agron Tufa, Arian Leka, Arshi Pipa, Bardhyl Londo, Lindita Arapi, Liri Seitllari, Luljeta Lleshanaku, Valdete Antoni, Josif Papagjoni, Majlinda Nana Rama, Mihal Hanxhari, Mimoza Ahmeti, Nazmi Seitaj, Parid Teferiçi, Sadik Bejko, Xhezair Abazi, Preç Zogaj, Romeo Çollaku, Rudolf Marku, Irena Gjoni, Ylljet Aliçka, Astrit Bishqemi, Gaqo Bushaka, Alfred Çapaliku, Primo Shllaku, Rudi Erebara, and some other writers and researchers who, for now, we cannot recall so as to count all of them in this article, limited by the space of writing. But, they are writers whom the Albanian readers know well because, based on some surveys done at book fairs (in Tirana, Prishtina, Tetovo, Tuz), they have mentioned their works and have even talked about the content of the books they had read. And, finally, we should mention that their works have been published mainly by these publishers in Albania and Kosovo: Nëndori, Zëri i rinisë, Naim Frashëri, Rilindja, Libri shkollor, Onufri, Toena, Skanderbeg, Argeta, Buzuku, Faik Konica, Rozafa, UETPress with publication circulations, depending on the writer's fame, from 300 to 3,000 copies.

\section{The status of contemporary Albanian literature in the social life and education system}

As the researcher and poet Sadik Bejko notes, "with the political changes after the '90s, many of the meanings on society, history, literature, etc., were lost or some of the concepts that had led social opinion and sciences in general took other contents" (Bejko, 2009).

At the beginning of the ' 90 s in Albania, authors of this country had, more or less, the same fate as the authors from Kosovo and their works. "Teachers and university professors first cleansed their texts from flagrant politicization. Just as the omission of authors from programs had been done for political reasons, the first evaluations of authors and works of this kind were very politically coloring, but they were now on the other side. The political coloring on the other side was stigmatized by a joke that circulated Tirana in those years: we are passing from socialist realism to democratic realism. This happened because the persons who were making the changes were the same, and the same political orientation that had the biggest influence on the changes being made" (Bejko, 2009).

\section{Result and Conclusion}

Regarding contemporary Albanian literature, the authors and their works presented in this article, it is worth noting that many other writers who create literary works in different countries outside of Albania, Macedonia and Montenegro with motives of their country could not be presented here. Whenever the time comes to write a history book of the Albanian literature it can be estimated that this story will manifest itself in its own way with its deep history. It is this literature that makes us feel the story present in the fate of the writings that carry events, situations and ideas throughout history and also reflect the limitations of the writings through which the ruthless ideological reality was 
reflected. In time, the formal instrument is no longer in the service of a triumphant ideology; is a form of a new situation of the writer, who loses connection with time, namely the power that necessarily leads to the beautification of the existing reality. Because writing somehow assumes a neutral role, then the writer achieves a state of equality.

\section{References}

1. Aliu, Ali, Dëshmi letrare, Akademia e Shkencave dhe Arteve e Kosovës, Prishtinë, 2008.

2. Aliu, Ali, Letërsia bashkëkohore shqiptare : 4, Prishtinë, Albas, 2002.

3. Aliu, Ali, Kritikë dhe ese: letërsi e sotme shqipe, Rilindja, Prishtinë, 1971.

4. Elsie, Robert, Një fund dhe një fillim: vështrim mbi letërsinë dhe kulturën shqiptare bashkëkohore, Gjon Buzuku, Prishtinë, 1995.

5. Elsie, Robert, Historia e letërsisë shqiptare, Toena, Tiranë, 1997.

6. Basha, Doruntina, Drama bashkëkohore nga rajoni, Qendra Multimedia, Prishtinë, 2013.

7. Berisha N., Anton, Antologji e poezisë bashkëkohore të arbëreshëve të Italisë : 1946-1996, Mësonjëtorja, Tiranë, 2002.

8. Bihiku, Koço, Historia e letërsisë shqiptare të realizmit socialist, Naim Frashëri, Tiranë, 1978.

9. Çapriqi, Basri, Format antitetike të tekstit letrar $n \ddot{e}$ poezinë e sotme shqipe, (master thesis), Universiteti $\mathrm{i}$ Prishtinës, Fakulteti Filozofik, Prishtinë, 1987.

10. Çapriqi, Basri, Simboli në poezinë e sotme shqipe, (doctoral thesis), Universiteti i Prishtinës, Fakulteti i Filologjisë, Prishtinë, 2004.

11. Daci, Fatos, Antologji e poezisë dibrane, Kristalina$K H$, Tiranë, 2005.

12. Islami, Nebi, Historia dhe poetika e dramës shqiptare I-II (1886-1996), Universiteti i Prishtinës, Fakulteti i Arteve Dramatike, Prishtinë, 2003.

13. Ismajli, Rexhep, Poezia e sotme arbëreshe, Rilindja, Prishtinë, 1990.

14. Jorgaqi, Nasho, Antologji e poezisë bashkëkohore arbëreshe, Dudaj, Tiranë, 2001.

15. Kelmendi, Shpëtim, Antologji e prozës bashkëkohore shqiptare, Ombra, Tiranë, 2004.

16. Kelmendi, Ramiz, Tregime të sotme shqiptare, Enti i Botimeve Shkollore i Republikës Socialiste të Serbisë - Reparti Prishtinë, 1969.

17. Koiçiçi, Abedin, Formimi i fjalëve dhe vlerat e tij në prozën e sotme shqipe në Kosovës : (mbështetur në veprat e autorëve Anton Pashku e Rexhep Qosja), Geer, Tiranë, 2011.

18. Kuçuku, Bashkim, Antologji e poezisë shqipe bashkëkohore, Onufri, Tiranë, 2008.

19. Kuçuku, Bashkim, Letërsia shqiptare, 4, Libri Shkollor, Prishtinë, 2004.

20. Kuçuku, Bashkim [et al.], Zemra e qiellit : antologji e poezisë shqipe të shekullit XX, PEN Qendra e Kosovës, Prishtinë, 2015.

21. Lami, Sevi, Antologji e poezisë së "A dangerous method", Albas, Tiranë; Prishtinë; Tetovë, 2015.

22. Metaj, Zeqir, Drama e sotme shqipe në Jugosllavi, (master thesis), Universiteti i Prishtinës, Fakulteti Filozofik, Prishtinë, 1984.

23. Mulliqi, Haqif, Teatri, drama dhe identiteti kulturor në Kosovë, Armagedoni, Prishtinë, 2017.

24. Prendi, Arben, Letërsi shqipe bashkëkohore: ndërthurja e poetikave dhe çkodimi i realiteteve metafizike në romanin bashkëkohor bën edhe studiuesi.

25. Prendi, Arben, Probleme, autorë dhe vepra nga letërsia shqipe bashkëkohore, Shkodër, 2017.

26. Qosja, Rexhep, Transformimet dhe kontinuitetet $e$ letërsisë shqipe në Jugosllavi, shih Seminari i Kulturës Shqiptare për të Huaj, Universiteti i Prishtinës, Fakulteti Filozofik, 1976 https://drive.google.com/file/d/0B2 VOhY4GgeRW Xh2UX1wdXY4U3c/edit

27. Qosja, Rexhep, Prej tipologjisë deri te periodizimi, Rilindja, Prishtinë, 1979.

28. Radogoshi, Kadrush, Poetika e romanit bashkëkohor shqiptar me tematikë të shekullit XV, (tezë magjistrature, UP, Fakulteti Filozofik, 1985.

29. Raifi, Mensur, Mbi poezinë bashkëkohore shqiptare, Rilindja, 1977.

30. Ramadani, Sinan, Vendlindja në poezinë e sotme shqipe, (master thesis), Universiteti i Prishtinës, Fakulteti Filozofik, Prishtinë, 1986.

31. Rexhaj, Besim, Drama shqiptare pas Luftës së Dytë Botërore 1948-2008: poetika, tipologjia, periodizimi, Faik Konica, Prishtinë, 2009.

32. Rugova, Ibrahim [et al.], Lulet në ballkon : antologji e poezisë më të re të Kosovës, Zëri i rinisë, Prishtinë, 1982. 
33. Rugova, Ibrahim, Kahe dhe premisa të kritikës letrare shqiptare (1504-1983), Rilindja, Prishtinë, 1986.

34. Rugova, Ibrahim, Refuzimi estetik, Rilindja, Prishtinë, 1987.

35. Rrahmani, Kujtim, Letërsia bashkëkohore, 13, Albas, Tiranë, 2006.

36. Sadiku, Sinan, Rendi $i$ vlerave në poezinë bashkëkohore shqiptare, "Beqir Musliu", Gjilan, 2013.

37. Sejdiu, Vaxhid, Poema e sotme shqipe me temë historike, (master thesis), Universiteti i Prishtinës, Fakulteti i Filologjisë, Prishtinë, 2005.

38. Simpozium Rrjedhat e letërsisë bashkëkohore shqiptare nga gjysma e dytë e shekullit XX - poezia, proza dhe drama, AShAK, Prishtinë, 2005.

39. Shema, Isak, Kultura letrare bashkëkohore, Lidhja e Shkrimtarëve e Kosovës, Prishtinë, 2015.

40. Vinca, Agim, Struktura e zhvillimit të poezisë shqipe: (1945-1980), Rilindja, Prishtinë, 1985. 